\title{
THE IOURNAL OF
}
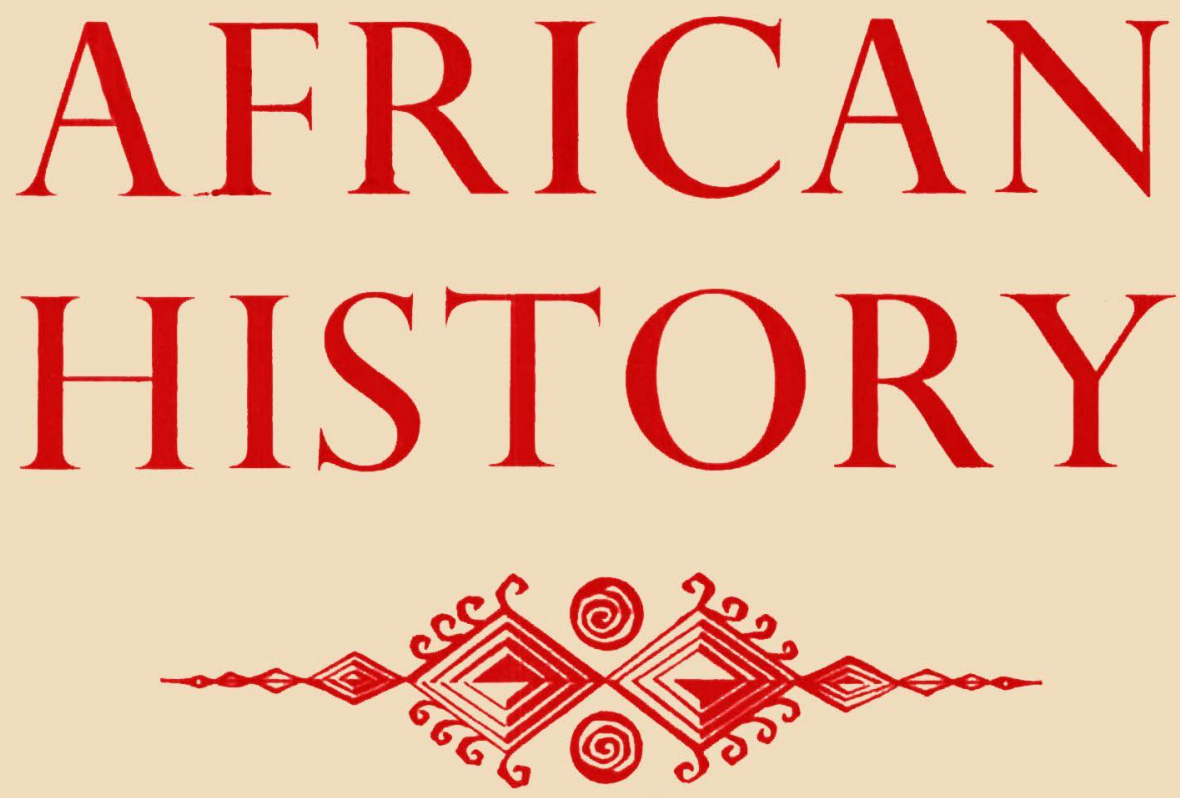

EDITED BY

J. D. FAGE, J. R. GRAY,

S. MARKS \& R. A. OLIVER

$$
\text { VOLUME XII · I97I · NUMBER } 3
$$

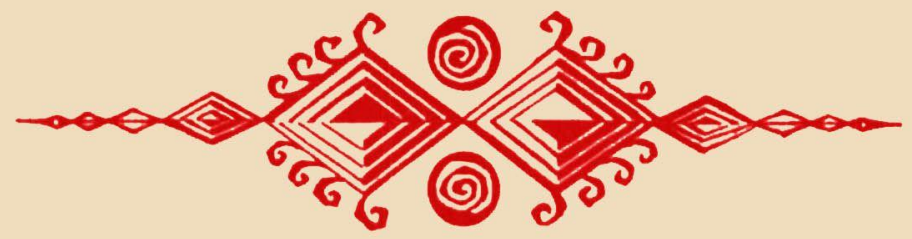

\section{CAMBRIDGE UNIVERSITY PRESS}

EI.50NET $\$ 4.75$ IN U.S.A. SUBSCRIPTION PRICE $£ .5 .00 \cdot \$ 17.00$ IN U.S.A. 


\section{THE JOURNAL, OF AFRICAN HISTORY}

ADVISORY EDITORIAL BOARD

J. F. Ade Ajayi (Ibadan) J. M. Lonsdale (Trinity College,

A. Adu Boahen (Legon) Cambridge)

$\begin{aligned} \text { IIfari Brunscuwig(École Pratique } & \text { G. Mathew (Oxford) } \\ \text { des Hautes Études, Paris) } & \text { B. A. Ogot (University of Nairobi) } \\ \text { J. I)esmond ('lark (University of } & \text { Yves Person (Paris) } \\ \text { California, Berkeley) } & \text { J. Stengers (Universite Libre, } \\ \text { Puimp D. ('urtin (Wisconsin) } & \text { Brussels) }\end{aligned}$

SIIIISCRIPTIONS

The Yournal of African Ilistory is published quarterly.

Single parts $f_{1} 1.50$ net $(\$ 4.75$ in the U.S.A.).

Four parts form a volume. The subscription price of a volume (which includes postage) is $f .5 .00$ net $(\$ 17.00$ in the U.S.A.).

Orders may be sent to a bookseller or to the publisher.

Copies of the journal for subscribers in the United States of America are sent by air to New York to arrive with minimum delay.

Second class postage paid at New York, N.Y.

PUBLISHED BY

THE SYNIICS OF THE CAMBRIDGE UNIVERSITY PRISS

Bentley House, 200 Euston Road, London NW 2 I) B American Branch: 32 East 57th Street, New York, N.Y. 10022 